\title{
A Single Disease with Double
Complications: Crohn's Disease
}

\author{
Bir Hastalık, Iki komplikasyon: Crohn Hastalığı
}

Aysun Yakar ${ }^{1}$, Fatih Yakar ${ }^{2}$, Fatmanur Karaköse² ${ }^{2}$ Hatice K. Özçelik², Kübra Aşık²

\begin{abstract}
Crohn's disease $(C D)$ is a chronic inflammatory disease of the gastrointestinal tract. Extra intestinal manifestations of $C D$ may involve almost every organ system. Thrombosis and thromboembolic events are more frequent than in the normal population; additionally, drugs that are used to control disease activity have many side effects. One of the main problems associated with these drugs are immunosuppression, which may lead to many infections and malignancy. We present a case of 62-year-old woman, who has been diagnosed with Crohn's disease. She was admitted with complaints of shortness of breath. The patient was diagnosed with pulmonary thromboembolism through computerized tomography during admission. Low molecular weight heparin was initiated. During treatment, a skin discoloration was noticed in her lower extremities, and after thorough evaluation, the patient was diagnosed Kaposi's sarcoma by a skin biopsy. Although thromboembolic events are expected during inflammatory diseases, Kaposi's sarcoma development is not. We identified the immunosuppression as the most probable cause of Kaposi's sarcoma development.
\end{abstract}

Key words: Crohn's disease, pulmonary thromboembolism, Kaposi's sarcoma, inflammatory bowel disease.

\section{Özet}

Crohn hastalığı, gastrointestinal sistemin kronik inflamatuar bir hastalığıdır. Hastalık, gastrointestinal sistemin herhangi bir bölümünü tutabildiği gibi, neredeyse tüm organ sistemlerde de ekstraintestinal semptomlara neden olabilir. Crohn hastalarında tromboz ve tromboembolik olaylar normal popülasyondan daha sık görülür. Aynı zamanda hastalığın aktivitesini kontrol altına almak için kullanılan ilaçların da birçok yan etkisi vardır. Bu ilaçlarla ilgili ana problemlerden biri immünsüpresyon olup enfeksiyonlara veya maligniteye yol açabilir. Crohn hastalığı tanısı olan 62 yaşında bayan hasta, nefes darlığı şikâyetiyle başvurdu. Çekilen toraks bilgisayarlı tomografisinde pulmoner tromboemboli saptandı ve düşük moleküler ağırlıkı heparin tedavisi başlandı. Tedavi süresinde alt ektremitede renk değişim farkedildi. Yapılan cilt biyopsisinde Kaposi sarkomu tanısı kondu. Her ne kadar inflamatuar hastalıklarda tromboembolik olaylar gelişebilse de, sarkom gelişmi beklenmemektedir. Diğer tüm nedenler dışlandıktan sonra hastada en muhtemel neden hastalığı kontrol etmek için kullanılan immünsüpresif tedavi olarak belirlendi.

Anahtar Sözcükler: Crohn hastalığı, Pulmoner tromboemboli, Kaposi sarkomu, Inflamatuar barsak hastalı̆̆ı.
'İstanbul Forensic Science Institute, Ministry of Justice, İstanbul Turkey

${ }^{2}$ Department of Pulmonary Medicine, Bezmialem Vakıf University Faculty of Medicine, İstanbul, Turkey
'İstanbul Adli Tıp Kurumu, Adalet Bakanlığı, İstanbul ${ }^{2}$ Bezmialem Vakıf Üniversitesi Tıp Fakültesi, Göğüs Hastalıkları Anabilim Dalı, İstanbul

Submitted (Başvuru tarihi): 27.10.2014 Accepted (Kabul tarihi): 25.12.2014

Correspondence (iletişim): Kübra Assık, Department of Pulmonary Medicine, Bezmialem Vakıf University

Faculty of Medicine, İstanbul, Turkey

e-mail: ka.kubraasik@gmail.com 
Inflammatory bowel disease (IBD) commonly refers to ulcerative colitis (UC) and Crohn disease (CD), which are chronic inflammatory diseases of the gastrointestinal tract. Although the etiology of IBD is unknown, environmental, infectious, genetic, autoimmune, and host factors have been suspected. Interactions among these factors may be more important (1). The disease may affect both genders and nearly all age groups (2).

Extra-intestinal manifestations (EIMs) of inflammatory bowel disease (IBD) have been reported to involve almost every organ system. The prevalence of at least one EIM in recent population-based studies of patients with IBD ranges from $6 \%$ to $47 \%$ (1). Not only the diseases, but also the drugs, that are used to control the disease activity may cause many side effects. The most important side effect is immunosuppression $(3,4)$.

The current report describes a patient with Crohn's disease-induced pulmonary thromboembolism and Kaposi's sarcoma.

\section{CASE}

A 62-year-old woman was admitted to our clinic with complaints of cough, sputum, and shortness of breath. She had no history of smoking history, but diagnosed with type 2 diabetes mellitus, hypertension, and Crohn's disease, which was diagnosed four months prior. Methylprednisolone, cyclophosphamide, and mesalamine treatment was initiated four months ago. Her blood pressure was $115 / 60 \mathrm{mmHg}$. She was hospitalized for hypoxemic, hypercapnic respiratory failure $\left(\mathrm{PaO}_{2}: 45 \mathrm{mmHg}\right.$, $\left.\mathrm{PaCO}_{2}: 50 \mathrm{mmHg}, \mathrm{pH}: 7.4, \mathrm{HCO}_{3}: 28 \mathrm{meq} / \mathrm{L}\right)$ at room air. Widespread superficial varices on both lower extremities and a $6 \times 4 \mathrm{~cm}$ brown-colored lesion with radial extension to the periphery on right anterolateral of tibia were present upon inspection (Figure 1). The respiratory examination revealed an increased respiratory rate (24 breaths/minute) and biphasic rhonchi. The pulmonary function test (PFT) resulted forced vital capacity (FVC): $1290 \mathrm{ml},(55 \%)$, forced expiratory volume in 1 second (FEV1): $970 \mathrm{ml},(50 \%)$ and a ratio of FEVI/FVC $75 \%$. The laboratory evaluation demonstrated a normal leukocyte count, erythrocyte sedimentation rate of 40 $\mathrm{mm} /$ hour, and CRP of $1.6(\mathrm{~N}: 0-0.5) \mathrm{mg} / \mathrm{l}$. Urine analysis revealed $(3+)$ proteinuria and $0.5 \mathrm{gr}$ proteinuria with Esbach's method. There was no abnormal finding except plate atelectasis at the lower left zone of the posteroanterior chest $\mathrm{x}$-ray (Figure 2). We performed thorax computerized tomography (CT) to explain the hypoxemia and assess the lung involvement of Crohn's disease. There were widespread pulmonary thrombi at both pulmonary arteries with coexisting plate atelectasis in the lower left lobe (Figure $3 a$ and $b$ ). The transthoracic Echocardiography revealed stage 1 diastolic dysfunction, minimal mitral regurgitation, normal left ventricular systolic functions (ejection fraction: 65\%), systolic pulmonary arterial pressure: $35 \mathrm{mmHg}$, and no right ventricular dysfunction.

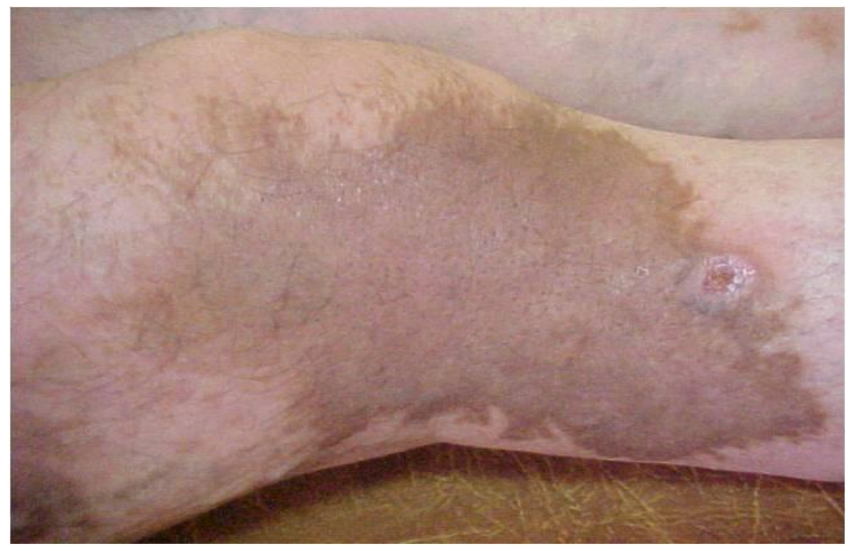

Figure 1: The brown-colored skin lesion; the outer circular lesion shows the biopsy site

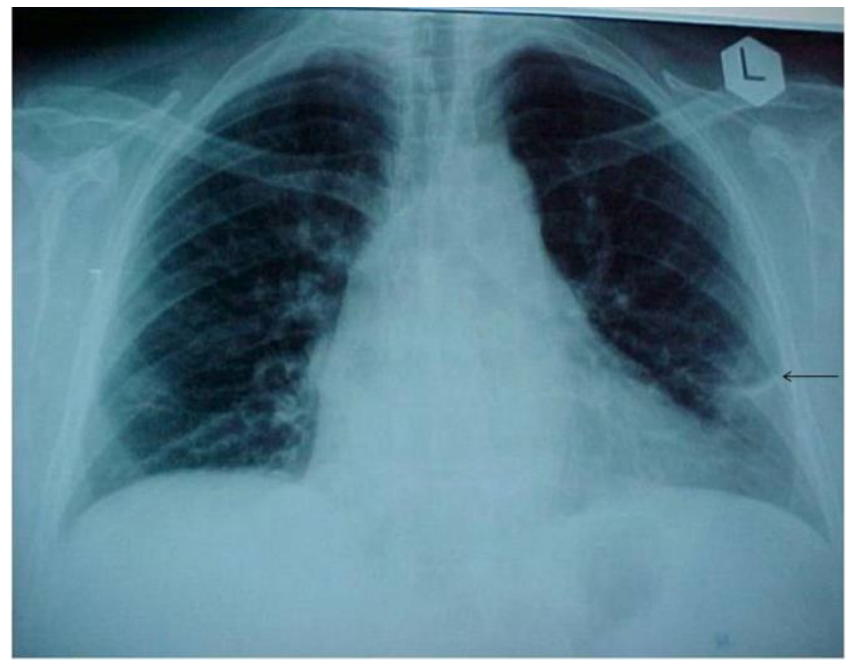

Figure 2: Chest x-ray: plate atelectasis at the left lower zone (black arrow)

The patient diagnosed with a non-massive pulmonary thromboembolism. Low molecular weight heparin was initiated according to body weight. Doppler ultrasound of venous lower extremities did not reveal thrombosis. The eye examination revealed hypertensive retinopathy. After bronchodilator treatment, biphasic rhonchi resolved, and improvement was observed at the control PFT (FVC: $1710 \mathrm{ml}(74 \%), \mathrm{FEV} 1: 1380 \mathrm{ml}(72 \%)$, and a ratio of $75 \%$ ). Mean blood pressure was $120 / 80 \mathrm{mmHg}$. Arterial blood gas analysis revealed the following: $\mathrm{PaO}_{2}: 82$ $\mathrm{mm} / \mathrm{Hg}, \mathrm{PaCO}_{2}: 39 \mathrm{~mm} / \mathrm{Hg}$ in ambient air. 
The dermatology consultation for the skin lesion raised the suspicion of Kaposi's sarcoma after a thorough examination and the elimination of other possible skin diseases. The skin biopsy from the lesion in the lower right extremity was obtained and revealed the diagnosis of Kaposi's sarcoma. HIV serology was negative with both ELISA and Western blot techniques. While the treatment for pulmonary embolism was on-going, the patient was referred to the dermatology department for Kaposi's sarcoma followup.
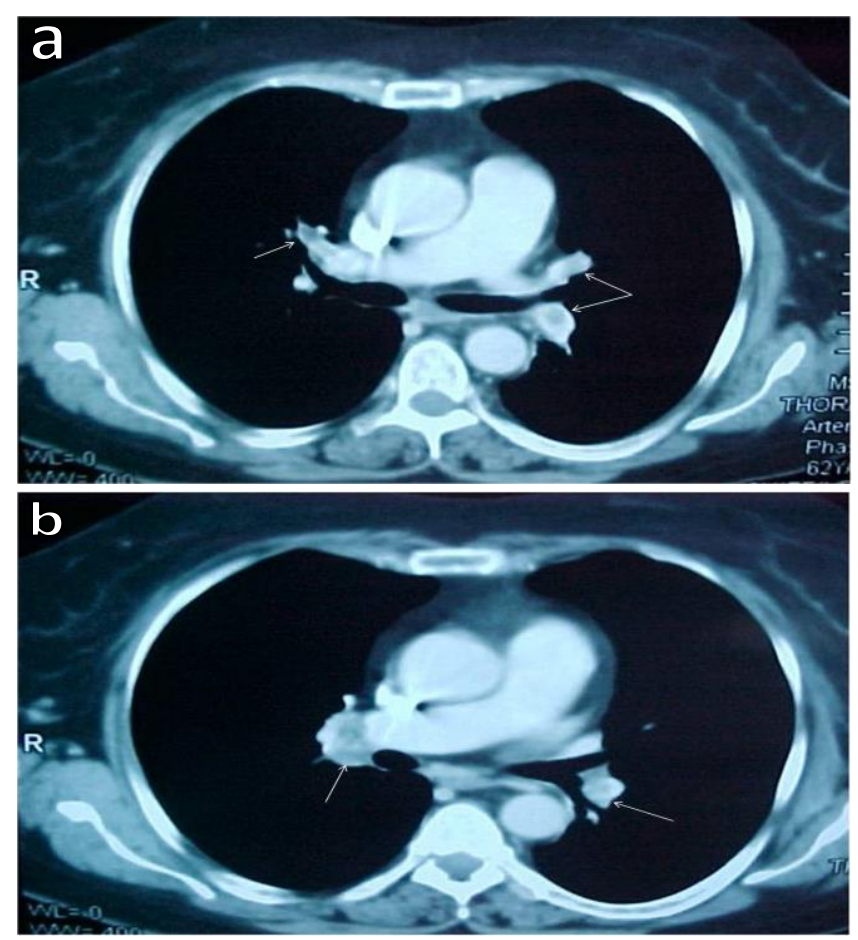

Figure 3a and b: Pulmonary thrombi at both pulmonary arteries (white arrows show the thrombi)

\section{DISCUSSION}

Respiratory involvement in patients with inflammatory bowel disease (IBD) has been reported since $1986(5,6)$. Thrombocytosis and thromboembolic events resulting from a hypercoagulable state in patients with IBD can lead to pulmonary embolism or thrombosis elsewhere in the body (7). Factors such as inflammation, fluid depletion, immobilization, surgery, steroid therapy, and the use of central venous catheters are prothrombotic risk factors in patients with IBD. The development of thromboses may be related to thrombocytosis and an increase in acutephase reactants during active inflammation (1).

Due to the nonspecific presentation of pulmonary embolism, the differential diagnosis is varied and extensive, especially in hospitalized patients with coexisting cardiac or pulmonary disease. Common considerations include congestive heart failure, exacerbation of chronic lung disease, postoperative atelectasis, and viral pleurisy. Arterial blood gas analysis is helpful but not diagnostic. Arterial hypoxemia and hypocapnia are usually present with embolism. Hypercapnia, on the other hand, is rare (8). Hypercapnia appears with embolism only in patients with marked antecedent ventilation limitations or when such limitations have been imposed because the patient is on controlled mechanical ventilation when embolism occurs (8). The current patient was initially diagnosed with obstructive pulmonary disease because of hypoxic hypercapnic respiratory failure. A CT scan was conducted for the pulmonary involvement of Crohn's disease and diagnosed pulmonary thromboembolism.

A population-based study in adults suggests that IBD patients have a three-fold greater risk compared to subjects without IBD of developing deep venous thrombosis and pulmonary embolism (1). Thrombosis has been reported in $1.8 \%$ of patients with UC and $3.1 \%$ of patients with CD (1).

Toruner et al. (9) showed that the prothrombotic gene may be present in IBD patients. Although Factor $V$ Leiden mutation is the most frequent cause of inherited thrombophilia (1), inherited thrombophilia markers (Factor $V$ Leiden and Prothrombin 20210A) were negative at this case. The Doppler ultrasound was also negative for thrombus. These findings led to the thought that the etiology of thrombus may be induced through an underlying disease.

Cases with ulcerative colitis or Crohn's disease that developed varied bronchopulmonary problems were reported by Camus et al. (10). These include: 1) airway inflammation: in the form of subglottic stenosis, chronic bronchitis, severe chronic bronchial suppuration, bronchiectasis, and chronic bronchiolitis; 2) varied patterns of interstitial lung disease: mainly bronchiolitis obliterans with organizing pneumonia, pulmonary infiltrates, and eosinophilia; and 3) miscellaneous other forms of involvement including striking neutrophilic necrotic parenchymal nodules and serositis (11).

Kaposi's sarcoma is a rare and slowly progressive spindle-cell tumor thought to be derived from the endothelial cells and primarily affects the skin. It can be accompanied by a range of symptoms from minimal mucocutaneous disease to extensive organ involvement. There are mainly four types of Kaposi's sarcoma: epidemic of AIDS-related, immunocompromised, classic or sporadic, and endemic (African) (12-14).

This entity can occur following solid-organ transplantation or in patients receiving immunosuppressive therapy. Alt- 
hough the incidence of Kaposi's sarcoma is increased 100 -fold in transplant patients $(15,16)$, it is extremely rare in the patients receiving the treatment for inflammatory bowel disease $(16,17)$. Our patient was HIV negative and there were no other risk factors such as infrequent bathing, chronic steroid requiring dermatitis, and the patient did not live in any territory that was endemic of Kaposi's sarcoma in Africa. In this case, the most probable cause was immunosuppressive therapy for Crohn's disease.

As a conclusion, patients with Crohn's disease should be under supervision for pulmonary involvement and shortness of breath with an acute onset should raise the suspicion of pulmonary embolism even without any evident probable cause. Additionally, clinicians should be aware of side effects of immunosuppressive drugs, including sarcoma development.

\section{CONFLICTS OF INTEREST}

None declared.

\section{AUTHOR CONTRIBUTIONS}

Concept - A.Y., F.Y., F.K., H.K.Ö., K.A.; Planning and Design - A.Y., F.Y., F.K., H.K.Ö., K.A.; Supervision - A.Y., F.Y., F.K., H.K.Ö., K.A.; Funding - F.K., H.K.Ö.; Materials - A.Y.; Data Collection and/or Processing - K.A.; Analysis and/or Interpretation - A.Y., F.Y., F.K., H.K.Ö., K.A.; Literature Review - F.K., K.A.; Writing - F.Y., F.K. A.Y.; Critical Review - A.Y., F.Y., F.K., H.K.Ö., K.A.

\section{YAZAR KATKILARI}

Fikir - A.Y., F.Y., F.K., H.K.Ö., K.A.; Tasarım ve Dizayn A.Y., F.Y., F.K., H.K.Ö., K.A.; Denetleme - A.Y., F.Y., F.K., H.K.Ö., K.A.; Kaynaklar - F.K., H.K.Ö.; Malzemeler - A.Y.; Veri Toplama ve/veya İşleme - K.A.; Analiz ve/veya Yorum - A.Y., F.Y., F.K., H.K.Ö., K.A.; Literatür Taraması - F.K., K.A.; Yazıyı Yazan - F.Y., F.K. A.Y.; Eleştirel İnceleme - A.Y., F.Y., F.K., H.K.Ö., K.A.

\section{REFERENCES}

1. Jose FA, Heyman MB. Extraintestinal manifestations of inflammatory bowel disease. J Pediatr Gastroenterol Nutr 2008; 46:124-33. [CrossRef]

2. Karaahmet F, Kılıncalp S, Akıncı H, Hamamcı M, Coban $S$, Yuksel I. A disease affecting all ages: Crohn's disease. J Am Geriatr Soc. 2014; 62:1200-1. [CrossRef]

3. Hanaver SB. Medical management of Crohn's disease: treatment algorithms 2009. Dig Dis 2009; 27:536-41. [CrossRef]
4. Van Assche G, Vermeire S, Rutgeerts P. Immunosuppression in inflammatory bowel disease: traditional, biological or both? Curr Opin Gastroenterol 2009; 25:323-8. [CrossRef]

5. Bonniere $P$, Wallaert $B$, Cortot $A$, Marchandise $X$, Riou $Y$, Tonnel $A B$, et al. Latent pulmonary involvement in Crohn's disease: biological, functional, bronchoalveolar lavage and scintigraphic studies. Gut 1986; 27:919-25. [CrossRef]

6. Roisin RR, Barbera JA. Pulmonary Complications of Abdominal Disease. In: Murray JF, Nadel JA (eds). Murray and Nadel's textbook of respiratory medicine. Vol 2. 4th edition. Philadelphia: Elsevier Saunders, 2005:2226-7.

7. Nylund CM, Goudie A, Garza JM, Crouch G, Denson LA Venous thrombotic events in hospitalized children and adolescents with inflammatory bowel disease. J Pediatr Gastroenterol Nutr 2013; 56:485-91. [CrossRef]

8. Penn I. Cancer in the immunosuppressed organ recipient. Transplant Proc 1991; 23:1771-2.

9. Törüner $M$, Erkan $O$, Soykan I, Bozdayi $M$, Cetinkaya $H$, Yurdaydin $C$, et al. Factor $V$ Leiden, prothrombin G20210A and MTHFR gene mutations in inflammatory bowel disease. Turk J Gastroenterol 2004; 15:250-2.

10. Camus P, Piard F, Ashcroft T, Gal AA, Colby TV. The lung in inflammatory bowel disease. Medicine (Baltimore) 1993; 72:151-83. [CrossRef]

11. Yilmaz A, Demirci NY, Hoşgün D, Uner E, Erdoğan $Y$, Gökçek $A$, et al. Pulmonary involvement in inflammatory bowel disease. World J Gastroenterol 2010; 16:4952-7. [CrossRef]

12. James, William; Berger, Timothy; Elston, Dirk. Andrews' Diseases of the Skin: Clinical Dermatology. 10th ed. New York: Saunders:2005.

13. Olsen SJ, Chang Y, Moore PS, Biggar RJ, Melbye M. Increasing Kaposi's sarcoma-associated herpesvirus seroprevalence with age in a highly Kaposi's sarcoma endemic region, Zambia in 1985. AIDS 1998; 12:1921-5.

14. Cook-Mozaffari P, Newton R, Beral V, Burkitt DP. The geographical distribution of Kaposi's sarcoma and of lymphomas in Africa before the AIDS epidemic. $\mathrm{Br} \mathrm{J}$ Cancer 1998; 78:1521-8. [CrossRef]

15. Penn I. Tumors after renal and cardiac transplantation. Hematol Oncol Clin North Am. 1993; 7:431-45.

16. Kang MJ, Namgung KY, Kim MS, Ko BS, Han CS, Ahn $\mathrm{HT}$, et al. A case of Kaposi's sarcoma associated with ulcerative colitis. Korean J Gastroenterol 2004; 43:316-9.

17. Meltzer SJ, Rotterdam HZ, Korelitz BI. Kaposi's sarcoma occurring in association with ulcerative colitis. Am J Gastroenterol 1987; 82:378-81. 